\title{
Retinoic acids promote the action of aromatase and $17 \beta$-hydroxysteroid dehydrogenase type 1 on the biosynthesis of $17 \beta$-estradiol in placental cells
}

\author{
S J Zhu, Y Li ${ }^{1}$, H Li, Y L Wang, Z J Xiao, P Vihko ${ }^{1}$ and Y S Piao \\ State Key Laboratory of Reproductive Biology, Institute of Zoology, Chinese Academy of Sciences, 19 Zhong Guan Cun Road, Beijing 100080, China \\ ${ }^{1}$ Biocenter Oulu and World Health Organization Collaborating Center for Research on Reproductive Health, University of Oulu, FIN-90014, Finland \\ (Requests for offprints should be addressed to Y S Piao; Email: piaoys@panda.ioz.ac.cn) \\ (S J Zhu is now at Department of Molecular and Integrative Physiology, University of Illinois at Urbana-Champaign, Urbana, Illinois 61801, USA)
}

\begin{abstract}
The biosynthesis of $17 \beta$-estradiol $\left(\mathrm{E}_{2}\right)$ in human placenta involves the actions of aromatase and $17 \beta$-hydroxysteroid dehydrogenase type 1 (17HSD1). Aromatase, an enzyme complex comprised of P450aromatase (P450arom) and NADH-cytochrome P450 reductase, converts androgens to estrogens, whereas 17HSD1 catalyzes the reduction of estrone to $\mathrm{E}_{2}$.

In the present study, the effects of retinoic acids (RAs) on P450arom and 17HSD1 expression in placental cells were investigated. Treatment with all-trans-RA (at-RA) or 9cis-RA increased $\mathrm{E}_{2}$ production in JEG-3 choriocarcinoma cells and cytotrophoblast (CTB) cells isolated from normal early placentas. Meanwhile, the activity of aromatase and expression of P450arom mRNA were induced by at-RA in JEG-3 cells. Northern blot analysis showed that the effect on P450arom mRNA expression occurs in a dose- and time-dependent fashion. Similar to at-RA and 9cis-RA, Ro40-6055, the retinoic acid receptor $\alpha(\mathrm{RAR} \alpha)$-selective activator, increased the expression
\end{abstract}

of P450arom and 17HSD1 mRNA in JEG-3 cells. On the other hand, Ro41-5253 (Ro41), the RAR $\alpha$-selective antagonist, blocked the stimulatory effect of RAs on P450arom expression. Surprisingly, Ro41 induced the activity and mRNA expression of 17HSD1 in JEG-3 cells, which is in contrast to the expected inhibitory effect and, moreover, remarkably potentiated the induction by at-RA and 9cis-RA. However, reporter gene analysis revealed that the influence of Ro41 on the transcription of the HSD17B1 gene, which encodes 17HSD1, is considerably milder in JEG-3 cells, and it only additively enhanced the effect of at-RA. Finally, it was found that at-RA and 9cis-RA increased the expression of P450arom and 17HSD1 mRNA in CTB cells, but to a lesser extent.

The data suggest that RAs may play a role in promoting the biosynthesis of $\mathrm{E}_{2}$ in the placenta. In addition, Ro41 has divergent effects on gene expression in JEG-3 cells.

Journal of Endocrinology (2002) 172, 31-43

\section{Introduction}

The placenta is a unique organ of the feto-maternal unit. It not only anchors the fetus physically to the uterus and co-ordinates the dialogue between the embryo and the maternal body, but it also acts as an endocrine unit for the production of the hormones needed by the maternal body and the fetal organs. In the human, the functions of the ovary gradually decline after fertilization and, concurrently, the placenta becomes the primary site of estrogen biosynthesis during pregnancy. By 7 weeks of gestation, nearly all estrogens in the circulation are produced by the placenta (Simpson \& MacDonald 1981). Unlike the ovary, the human placenta is not capable of de novo estrogen synthesis from cholesterol because of the absence of the $17 \alpha$-hydroxylase $/ \mathrm{C}_{17-20}$ lyase, which hydroxylates $\mathrm{C}_{21}$ steroids at position $\mathrm{C}_{17}$. Alternatively, it uses fetal-derived androgens, such as dehydroepiandrosterone (DHEA) and DHEA sulfate, as precursor molecules to synthesize estrogens (Albrecht \& Pepe 1990, Conley \& Mason 1990).

The biosynthesis of estrogens in the human placenta occurs in trophoblast cells, involving the action of two steroidogenic enzymes: aromatase and $17 \beta$-hydroxysteroid dehydrogenase type 1 (17HSD1). Aromatase catalyzes the aromatization of androgens to estrogens, for example, androstenedione (A-dione) to estrone $\left(\mathrm{E}_{1}\right)$ and testosterone to $17 \beta$-estradiol $\left(\mathrm{E}_{2}\right)$, the active form of estrogens, while 17HSD1 is responsible for the conversion of $\mathrm{E}_{1}$ to $\mathrm{E}_{2}$. Both enzymes are abundantly expressed in syncytiotrophoblast (STB) cells, the most active endocrine cell type in the placenta (Fournet-Dulguerov et al. 1987).

Aromatase is an enzyme complex that consists of two microsomal proteins: P450aromatase (P450arom) 
and NADH-cytochrome P450 reductase. The nonsteroidogenic cells transfected with the full-length P450arom cDNA are capable of aromatization of various $\mathrm{C}_{19}$ androgens to estrogens (Corbin et al. 1988, Pompon et al. 1989). Also, the dynamic changes in the P450arom mRNA level correlate well with aromatase activity (Evans et al. 1987). On the other hand, the reductase component of the aromatase complex is only modestly regulated (Steinkampf et al. 1987). These results indicate that aromatase activity is primarily determined by P450arom.

P450arom is encoded by the CYP19 gene, which contains 10 exons and 9 introns (Means et al. 1989). Compared with the other members of the P450 gene superfamily, the CYP19 gene is exceptionally large, over $250 \mathrm{~kb}$ in size. In the human, P450arom is expressed in various tissues, such as the ovary, placenta and adipose tissue (Means et al. 1991, Jenkins et al. 1993, Kilgore et al. 1993. Mahendroo et al. 1993, Toda \& Shizuta 1993). Selective use of distinct tissue-specific promoters and the subsequent post-transcriptional process using alternative polyadenylation signals at the $3^{\prime}$-ends of transcripts result in tissue-specific expression of a number of P450arom mRNA species (Simpson et al. 1994).

The gene encoding 17HSD1 is HSD17B1 (previously also called EDH17B2) containing two transcription start sites, which generate 1.3 and $2.3 \mathrm{~kb}$ mRNA species (LuuThe et al. 1990, Peltoketo et al. 1992). Of these two transcripts, only the $1.3 \mathrm{~kb}$ mRNA is evidently believed to be translated into 17HSD1 protein (Miettinen et al. 1996). Our recent studies demonstrated that the transcription of the HSD17B1 gene is controlled by a promoter, a silencer and an enhancer located in the $5^{\prime}$-flanking region (Piao et al. 1995, 1997a, Leivonen et al. 1999). The cell specificity of the enhancer determines the cell-specific expression of the HSD17B1 gene (Piao et al. 1995).

In addition to being nutritional signals, derivatives of vitamin A called retinoids have been suggested to affect the function of placental trophoblast cells (Matsuo \& Strauss 1994). A number of studies have shown that retinoids regulate the biosynthesis of several placental hormones, such as progesterone, human chorionic gonadotropin (hCG) subunits, and placental lactogen (Kato \& Braunstein 1991, Matsuo \& Strauss 1994, Stephanou \& Handwerger 1995, Guibourdenche et al. 1998a,b). Also, retinoids induce leptin synthesis and secretion in STB cells (Guibourdenche et al. 1998c). Our previous work demonstrated that retinoic acids (RAs) induce 17HSD1 expression in choriocarcinoma cells (Piao et al. 1997b). In addition, a recent report showed that they have a stimulatory effect on aromatase activity in breast cancer cells (Mu et al. 2000). These data prompted us to further examine whether RAs affect $\mathrm{E}_{2}$ biosynthesis in placental cells. In the present study, we examined the effects of RAs on $\mathrm{E}_{2}$ biosynthesis in cultured human cytotrophoblast (CTB) cells and the JEG-3 choriocarcinoma cell line derived from human trophoblast. JEG-3 cells retain the capability of converting $\mathrm{C}_{19}$ steroids to estrogens (Bahn et al. 1981) and have been widely used for the study of the production of placental hormones. We have focused on how RAs, either independently or in combination with other factors, affect the expression of P450arom and 17HSD1. Our data suggest that RAs may promote the biosynthesis of $\mathrm{E}_{2}$ in the placenta.

\section{Materials and Methods}

\section{Chemicals and reagents}

The isotopes $\left[2,4,6,7-{ }^{3} \mathrm{H}\right] \mathrm{E}_{1}(101 \mathrm{Ci} / \mathrm{mmol}), \quad[2,4,6,7-$ ${ }^{3} \mathrm{H}_{\mathrm{E}} \mathrm{E}_{2}(98 \mathrm{Ci} / \mathrm{mmol})$ and $\left[1 \beta_{-}{ }^{3} \mathrm{H}\right] \mathrm{A}-$ dione $(24 \mathrm{Ci} / \mathrm{mmol})$ were obtained from Amersham Life Science (Little Chalfont, Bucks, UK). $\left[{ }^{3} \mathrm{H}\right]$ Acetyl coenzyme A $(200 \mathrm{mCi} / \mathrm{mmol}$, CAT assay grade) was from Du Pont NEN (Boston, MA, USA). $\left[\alpha-{ }^{32} \mathrm{P}\right] \mathrm{dCTP}(3000 \mathrm{Ci} /$ mmol) was purchased from Yahui Biomedical Engineering Inc. (Beijing, China). Epidermal growth factor (EGF), 8-bromo-adenosine-3', 5'-monophosphate, cyclic, free acid (8Br-cAMP), N-[(1-(2,3-dioleoyloxy)propyl)]$\mathrm{N}, \mathrm{N}$,-trimethyl-ammoniummethylsulfate (DOTAP) and chloramphenicol acetyl transferase (CAT) were the products of Boehringer Mannheim (Mannheim, Germany). Trypsin, DNase I, fetal calf serum (FCS), bovine serum albumin (BSA), all-trans RA (at-RA), interleukin-1 $\beta$ (IL-1 $\beta$ ), bovine insulin, DHEA, A-dione, $\mathrm{E}_{1}$ and $\mathrm{E}_{2}$ were from Sigma Chemical Co. (St Louis, MO, USA). 12-Otetratradecanoylphorbol-13-acetate (TPA) was supplied by Calbiochem-Novabiochem Inc. (La Jolla, CA, USA). AMV reverse transcriptase, Taq DNA polymerase, RNasin and restriction enzymes were obtained from Promega Co. (Madison, WI, USA). TRIzol reagent, nick translation system and media for cell culture were purchased from Gibco BRL-Life Technologics (Grand Island, NY, USA). Plates for cell culture were obtained from Nunc Inter Med (Roskilde, Denmark). 9cis-RA, the selective retinoic acid receptor (RAR $\alpha$ ) activator Ro406055 (Ro40) and inhibitor Ro41-5253 (Ro41) were gifts from F Hoffmann-La Roche Ltd (Basel, Switzerland). The antiserum against $\mathrm{E}_{2}$ was raised in this laboratory and has been used in previous studies (Zhuang \& Li 1991, Rong-Hao et al. 1996). The plasmid containing human P450arom cDNA was provided by Professor Olavi Pelkonen (Department of Pharmacology, University of Oulu, Finland).

\section{Cell culture}

JEG-3 choriocarcinoma and T47D breast cancer cell lines were obtained from the American Type Culture Collection (Rockville, MA, USA). JEG-3 cells were maintained in Dulbecco's Modified Eagle's Medium (DMEM) supplemented with 10\% FCS, 2 mM glutamine, 
$1 \mathrm{mM}$ sodium pyruvate, $100 \mathrm{IU} / \mathrm{ml}$ penicillin, and $100 \mu \mathrm{g} / \mathrm{ml}$ streptomycin sulfate. T47D cells were cultured in RPMI 1640 medium containing 10\% FCS, $1 \mathrm{mM}$ non-essential amino acids and $0 \cdot 2$ IU insulin $/ \mathrm{ml}$. Before each experiment, the cells were detached with 0.025\% trypsin-0.02\% EDTA. JEG-3 cells were applied to 24-well plates $\left(2 \times 10^{5}\right.$ cells/well $)$ for $\mathrm{E}_{2}$ detection, 6 -well plates $\left(2.5 \times 10^{5}\right.$ cells/well) for the measurement of aromatase and reductive 17HSD activities, and $10 \mathrm{~cm}$ plates $\left(2.5 \times 10^{6}\right.$ cells/plate $)$ for Northern blot analysis. The cells were allowed to grow for $24 \mathrm{~h}$ and the media were then replaced with fresh ones containing 5\% FCS treated twice with dextran-coated charcoal (DCC-FCS), followed by culturing for a further $4 \mathrm{~h}$ before treatment. After that, the cells were subjected to various stimuli in media with 5\% DCC-FCS for the time indicated before the cells and media were collected for different assays.

The normal human placental tissues of 7-9 weeks of gestation were obtained from Beijing Haidian Hospital with the permission of the local ethics committee and the informed consent of the patients. The method for isolating and culturing CTB cells has been described in our recent studies (Xu et al. 2000, 2001). Briefly, the chorionic villi were collected from placental tissues and minced to $1 \mathrm{~mm}^{3}$ in size, followed by digestion of the samples with $0 \cdot 2 \%$ trypsin-10 units $/ \mathrm{ml}$ DNase I at $7-9{ }^{\circ} \mathrm{C}$ for $1 \mathrm{~h}$. The remaining undigested fragments were removed by filtration through a sieve (120 mesh). After gravity sedimentation through a BSA density gradient, the purified CTB cells were applied to type I collagen-coated 24-well plates $\left(2 \times 10^{5}\right.$ cells/well $)$ for the detection of $\mathrm{E}_{2}$ biosynthesis, and $60 \mathrm{~cm}$ plates $\left(2 \times 10^{6}\right.$ cells/plate $)$ for Northern blot analysis. The cells were cultured in FD medium (Ham's mixed nutrients F12:DMEM=1:1) containing $10 \mathrm{ng} / \mathrm{ml}$ EGF, $10 \mu \mathrm{g} / \mathrm{ml}$ insulin, $2 \mathrm{mM}$ glutamine and $0 \cdot 1 \%$ BSA for $36 \mathrm{~h}$ and then exposed to the same medium containing different stimuli for the time indicated.

\section{Analysis of the conversion of DHEA/A-dione to $E_{2}$ in cultured cells}

After treatment with various stimuli for $24 \mathrm{~h}, \mathrm{JEG}-3$ and CTB cells cultured in 24-well plates were washed twice with serum-free media (DMEM for JEG-3 cells and FD for CTB cells). Then, $1.0 \mathrm{ml}$ of the same media containing $500 \mathrm{nM}$ DHEA or A-dione was added to each well. The cells were incubated for $1 \mathrm{~h}$ at $37^{\circ} \mathrm{C}$ in cell culture conditions. After that, the media were collected and $\mathrm{E}_{2}$ concentration was determined by radioimmunoassay as described previously (Zhuang \& Li 1991).

\section{Measurement of aromatase and reductive 17HSD activities in cultured cells}

Aromatase activity was assessed by measuring the tritiated $\mathrm{H}_{2} \mathrm{O}$ produced by the specific release of tritium from $\left[1 \beta-{ }^{3} \mathrm{H}\right]$ A-dione (Thompson \& Siiteri 1974). In brief, JEG-3 cells, after exposure to various stimuli for the time indicated, were incubated in serum-free DMEM containing $1 \cdot 0 \times 10^{5}$ c.p.m. $\left[1 \beta^{3} \mathrm{H}\right] \mathrm{A}$-dione and $0 \cdot 2 \mu \mathrm{M}$ cold A-dione for $1 \mathrm{~h}$ at $37^{\circ} \mathrm{C}$. The reaction was stopped by adding $0.5 \mathrm{ml} \mathrm{30 \%}$ trichloroacetic acid to the media and then the plates were placed in an ice bath for $10 \mathrm{~min}$. After that, the media were extracted with $5 \mathrm{ml}$ diethyl etherethyl acetate (9:1) twice, for $15 \mathrm{~min}$ each time. A $900 \mu \mathrm{l}$ aliquot of the aqueous phase was measured in a scintillation counter.

Reductive 17HSD activity was determined by calculating the conversion rate of $E_{2}$ to $E_{1}$. After JEG-3 cells had been stimulated for $24 \mathrm{~h}$, the media were removed from the 6-well plates and $2 \mathrm{ml}$ serum-free medium containing $500 \mathrm{nM}$ unlabeled $\mathrm{E}_{1}$ and $2.5 \times 10^{6}$ c.p.m. of $\left[2,4,6,7-{ }^{3} \mathrm{H}\right] \mathrm{E}_{1}$ was added to each well. The cells were then incubated for $1 \mathrm{~h}$ at $37^{\circ} \mathrm{C}$ in cell culture conditions and the subsequent steps followed the method described previously (Miettinen et al. 1996).

\section{RNA isolation and Northern blot analysis}

Total RNAs from cultured cells were isolated using TRIzol reagent according to the manufacturer's instruction. Fifteen micrograms of each sample were resolved on $1 \cdot 0 \%$ agarose/formaldehyde gel and then transferred onto Hybond nylon membrane (Amersham International plc, Amersham, Bucks, UK) by pressure blotting. The subsequent steps followed a method described previously (Xu et al. 2000). The same membrane was separately probed by the ${ }^{32}$ P-labeled $1.0 \mathrm{~kb}$ EcoRI-SacI fragment of human 17HSD1 cDNA (Piao et al. 1997b), 1.4 kb SacI fragment of human P450arom cDNA (Ghersevich et al. 1994) and glyceraldehyde-3-phosphate dehydrogenase (GAPDH) cDNA. The autoradiographic signals were quantified by densitometry analysis with a Molecular Dynamics 300A computing densitometer (Molecular Dynamics, Sunnyvale, CA, USA).

\section{Transfection and CAT assay}

The construct pBL $(-661 /-392) \mathrm{CAT} 2$ containing 17HSDB1 enhancer has been used in our previous study (Piao et al. 1995). The enhancer is located at the region from -661 to -392 in the gene, with respect to the transcription start site for the $1.3 \mathrm{~kb} 17 \mathrm{HSD} 1 \mathrm{mRNA}$. Transient transfection experiments were performed as described previously (Piao et al. 1995). Briefly, the cells were applied to $6 \mathrm{~cm}$ plates in amounts of $7.5 \times 10^{5}$ cells/plate (JEG-3) or $1.5 \times 10^{6}$ cells/plate $($ T47D) and cultured for $24 \mathrm{~h}$ before transfection. Five micrograms of each plasmid construct were transfected into the cells using the transfection reagent DOTAP $(5 \cdot 0 \mu \mathrm{g} / \mathrm{ml})$. After $18 \mathrm{~h}$, the media were replaced and the cells were cultured for a further $48 \mathrm{~h}$ in the presence of various stimuli. 
Table 1 Summary of oligonucleotide primers used for RT-PCR

\begin{tabular}{|c|c|c|c|c|}
\hline \multirow[b]{2}{*}{ Gene } & \multicolumn{2}{|c|}{ Primer sequence $\left(5^{\prime} \rightarrow 3^{\prime}\right)$} & \multirow[t]{2}{*}{ Positions (nt) } & \multirow[t]{2}{*}{ size (bp) } \\
\hline & & & & \\
\hline \multirow[t]{2}{*}{ RAR $\alpha$} & Sense: & CTGCCCGACACCTGGGGGC & $123-141$ & \multirow[t]{2}{*}{160} \\
\hline & Antisense: & GTGTGGTAGGGGTCGGTGG & $264-282$ & \\
\hline \multirow[t]{2}{*}{ RAR $\beta$} & Sense: & TTCATGATTCGGGGCTGGGAAAAA & $322-345$ & \multirow[t]{2}{*}{154} \\
\hline & Antisense: & СGTTCССТСТАGTACAAAC & $457-475$ & \\
\hline \multirow[t]{2}{*}{$\operatorname{RAR} \gamma$} & Sense: & GACTCTITGCGGCTGGTGC & $434-452$ & \multirow[t]{2}{*}{162} \\
\hline & Antisense: & GGGTTCCTCTACCGGAGAG & $577-595$ & \\
\hline \multirow[t]{2}{*}{$\operatorname{RXR} \alpha$} & Sense: & ATGGACACCAAACATTTCCTGC & $76-97$ & \multirow[t]{2}{*}{268} \\
\hline & Antisense: & GGGACCCGAAGTCGTGAC & $325-343$ & \\
\hline \multirow[t]{2}{*}{$\operatorname{RXR} \beta$} & Sense: & ATGTCTTGGGCCGCTCGCC & $118-136$ & \multirow[t]{2}{*}{133} \\
\hline & Antisense: & GCTGCCGGGACCGACCTAG & $232-250$ & \\
\hline \multirow[t]{2}{*}{$\mathrm{RXR} \gamma$} & Sense: & GAGGСTCСССТGGССАСАC & $74-92$ & \multirow[t]{2}{*}{129} \\
\hline & Antisense: & GGTGCCTGAGACTCACGTC & $184-202$ & \\
\hline
\end{tabular}

After transfection, the cells were collected and subjected to four freeze-thaw cycles (freezing in dry ice/ethanol for $5 \mathrm{~min}$ and thawing at $37^{\circ} \mathrm{C}$ for $3 \mathrm{~min}$ ) in $150 \mu \mathrm{l} 0 \cdot 25 \mathrm{M}$ Tris- $\mathrm{HCl}(\mathrm{pH} 7 \cdot 8)$. The treatment was followed by heat inactivation at $65{ }^{\circ} \mathrm{C}$ for $20 \mathrm{~min}$, after which the CAT activity of the samples was measured by fluor diffusion assay (Neumann et al. 1987). Protein concentration was measured by a Bio-Rad protein assay system (Bio-Rad Laboratories, Richmond, CA, USA). CAT expression is described as $\mathrm{ng} / \mathrm{mg}$ protein resulting from comparison of the CAT activity in samples with the CAT standard curve.

\section{Reverse transcription-polymerase chain reaction (RT-PCR) analysis}

The primers used for RT-PCR analysis of retinoid X receptors (RXRs) and RARs are summarized in Table 1. Total RNA $(1 \cdot 0 \mu \mathrm{g})$ of JEG-3 cells was reversed transcribed using an oligo(dT) primer in a total volume of $20 \mu \mathrm{l}$. For PCR amplification, $2 \mu \mathrm{l}$ of RT products was added to a mixture $(50 \mu \mathrm{l})$ containing $20 \mathrm{mM}$ Tris $-\mathrm{HCl}$ (pH 8.4), $50 \mathrm{mM} \mathrm{KCl}, 1.5 \mathrm{mM} \mathrm{MgCl}_{2}, 0.25 \mathrm{mM}$ dNTPs, $1 \mu \mathrm{M}$ sense and antisense primers, and $5 \mathrm{U}$ Taq DNA polymerase. The reaction was performed in 30 sequential cycles at $94{ }^{\circ} \mathrm{C}$ for $20 \mathrm{~s}, 60^{\circ} \mathrm{C}$ for $30 \mathrm{~s}$, and $72{ }^{\circ} \mathrm{C}$ for $30 \mathrm{~s}$, using the GenAmp PCR System 2400 (Perkin-Elmer Corporation, Norwalk, CT, USA).

\section{Statistics}

All experiments were done at least twice, and statistical significance was determined by analysis of variance or Student's $t$-test where appropriate.

\section{Results}

Actions of RAs on $E_{2}$ biosynthesis in cultured JEG-3 and CTB cells

JEG-3 and CTB cells were treated with $100 \mathrm{nM}$ at-RA or 9cis-RA for $24 \mathrm{~h}$, and the capacity of treated cells to convert DHEA to $\mathrm{E}_{2}$ was examined by measuring the $\mathrm{E}_{2}$ concentration in the media. In JEG-3 cells, both at-RA and 9cis-RA stimulated $\mathrm{E}_{2}$ production over 2.2-fold (Fig. 1A). In CTB cells, at-RA and 9cis-RA caused 2.0and $2 \cdot 8$-fold increases in $\mathrm{E}_{2}$ synthesis respectively. Also, the conversion of A-dione to $\mathrm{E}_{2}$ in JEG-3 cells was increased over $2 \cdot 0$-fold by the same administration of at-RA or 9cis-RA (Fig. 1B).

Induction of aromatase activity by at- $R A, 8 B r-c A M P, T P A$ and IL-1 $\beta$ in JEG-3 cells

Since aromatase is involved in $\mathrm{E}_{2}$ biosynthesis, aromatase activity was analyzed after the treatment of JEG-3 cells with $0 \cdot 1-1000 \mathrm{nM}$ at-RA for $48 \mathrm{~h}$. Increased aromatase activity $(2 \cdot 0$-fold $)$ was detected after treatment with $0 \cdot 1 \mathrm{nM}$ at-RA, and the activity was further enhanced dose-dependently, reaching 3.8-fold at $1000 \mathrm{nM}$. On the other hand, when the cells were stimulated with $100 \mathrm{nM}$ at-RA, significantly increased aromatase activity $(4 \cdot 0$-fold) could be observed at $6 \mathrm{~h}$, and the induction remained for up to 48 h (Fig. 2).

In addition to at-RA, 8Br-cAMP, TPA (the protein kinase $\mathrm{C}$ activator) and IL- $1 \beta$ increased aromatase activity to different extents in JEG-3 cells. Furthermore, simultaneous administration of at-RA with $8 \mathrm{Br}-\mathrm{cAMP}$ or TPA potentiated the stimulatory effect of at-RA on aromatase activity, while IL- $1 \beta$ merely enhanced the induction in an additive manner (Fig. 3).

Effect of at-RA, 8Br-cAMP and TPA on the expression of P450arom $m R N A$ in JEG-3 cells

To elucidate whether the transcription of the CYP19 gene is affected, JEG-3 cells were treated for 6-48 h with different doses of at-RA, ranging from $0 \cdot 1$ to $1000 \mathrm{nM}$, and P450arom expression was determined by Northern blot analysis. Similar to the effect of at-RA on aromatase activity, an increased expression of P450arom mRNA was 

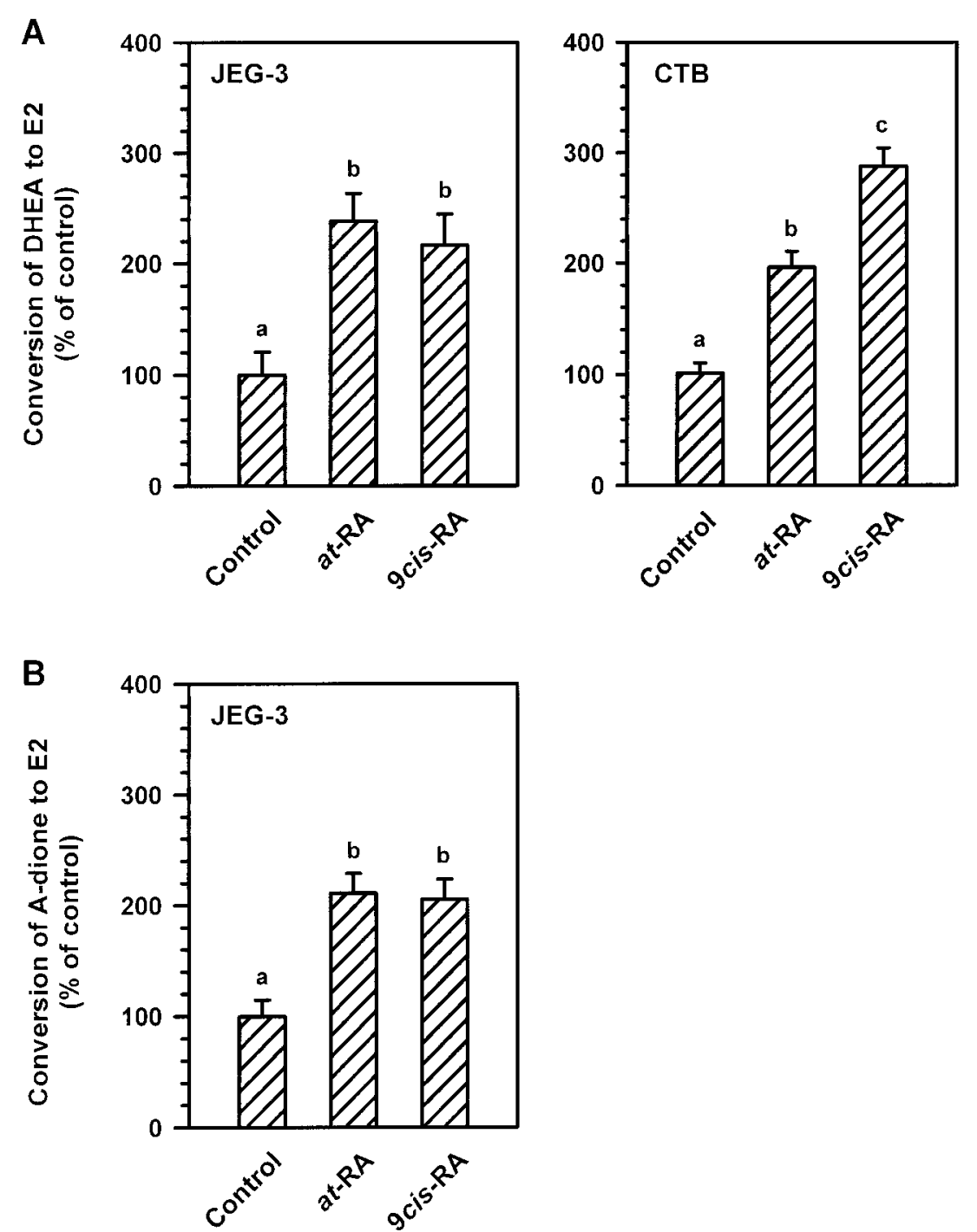

Figure 1 Action of RAs on $E_{2}$ biosynthesis in JEG-3 and CTB cells. Bars without the same letter are significantly different from each other $(P<0 \cdot 05)$. (A) JEG-3 cells and CTB cells were treated with $100 \mathrm{nM}$ at-RA or 9cis-RA for $24 \mathrm{~h}$, after which the cells were incubated with $500 \mathrm{nM}$ DHEA for $1 \mathrm{~h}$ in cell culture conditions. The data represent the means \pm S.D. of four (JEG-3) or three (CTB) independent experiments, with quadruplet samples in each. (B) JEG-3 cells were stimulated with $100 \mathrm{nM}$ at-RA or 9cis-RA for $24 \mathrm{~h}$ and then incubated with $500 \mathrm{nM}$ A-dione for $1 \mathrm{~h}$ in cell culture conditions. The data represent the means \pm S.D. of three independent experiments with duplicate samples in each.

observed after treatment of the cells with $0 \cdot 1 \mathrm{nM}$ at-RA, and the stimulation was further increased with the elevation of the at-RA concentration tested, reaching a 4.8-fold maximal value compared with the control level (Fig. 4, left panel). Unlike the influence on the enzyme activity, the induction on P450arom mRNA expression appeared to be time-dependent. Treatment of cells with $100 \mathrm{nM}$ at-RA caused a 1.4-fold increase in the mRNA level at $6 \mathrm{~h}$, and the stimulation continued to rise in parallel with the time-course, reaching $2 \cdot 7$-fold at $48 \mathrm{~h}$ (Fig. 4, right panel).

The influence of at-RA on CYP19 gene expression in JEG-3 cells was also examined in the presence of 8Br-cAMP and TPA. The expression of 3.0 and $2.4 \mathrm{~kb}$ P450arom mRNA was remarkably increased by treatment of the cells with $20 \mathrm{nM}$ TPA and especially $1.5 \mathrm{mM} 8 \mathrm{Br}$-cAMP. Both compounds further enhanced the effects of at-RA (Fig. 5). 

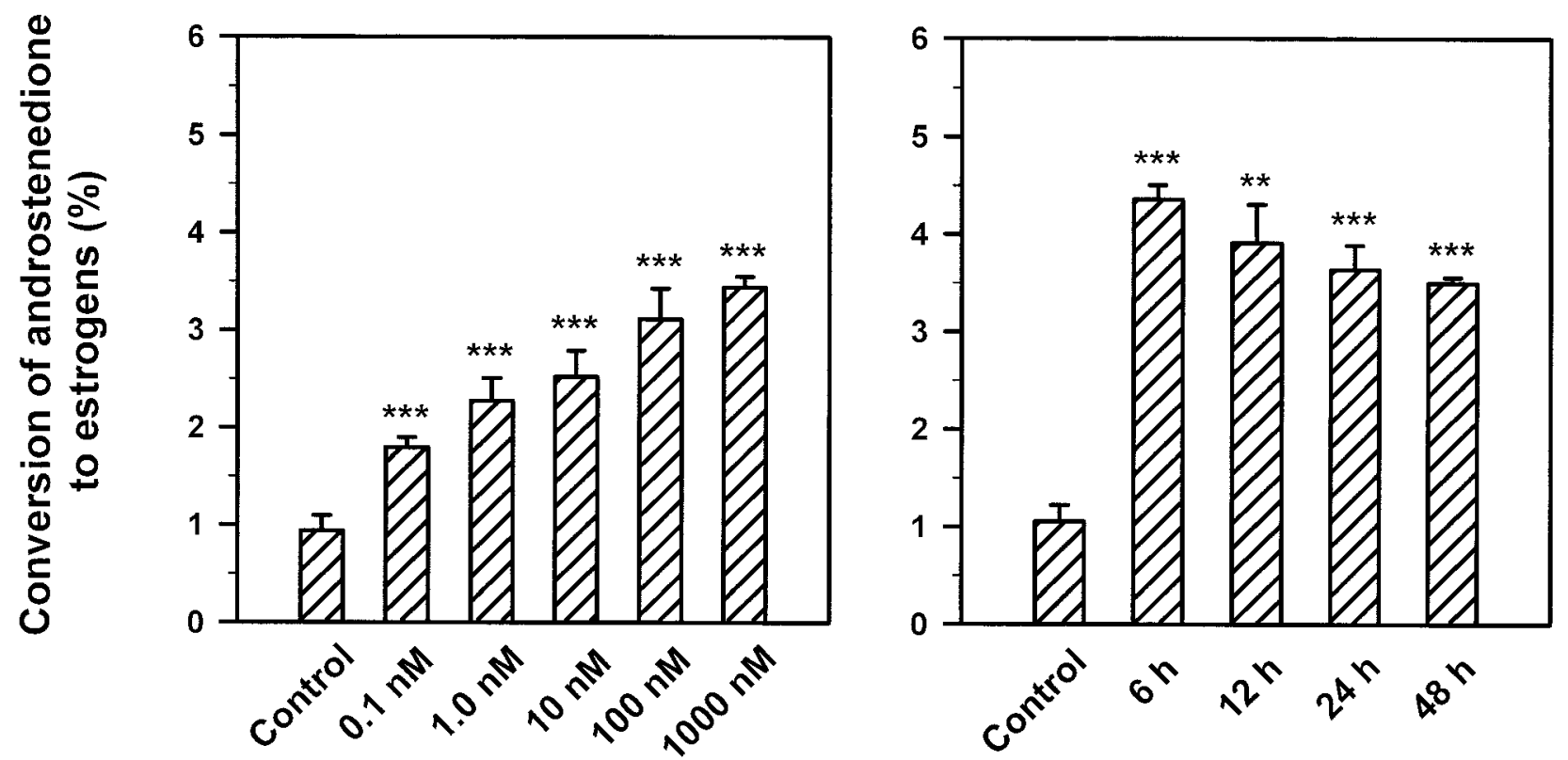

Figure 2 Effect of at-RA on aromatase activity in JEG-3 cells. Aromatase activity was examined after the cells had been treated with 0.1-1000 nM at-RA for $48 \mathrm{~h}$ (left panel), or $100 \mathrm{nM}$ at-RA for 6-48 h (right panel). The data show the means \pm S.D. of three independent experiments with duplicate samples in each. ${ }^{* *} P<0 \cdot 01,{ }^{* * *} P<0 \cdot 001$.

Effects of the selective RARa agonist Ro40 and antagonist Ro41 on the expression of P450arom and 17HSD1 $m R N A$ in JEG-3 cells

The effects of the selective RAR $\alpha$ agonist Ro40 and antagonist Ro41 on P450arom and 17HSD1 expression in JEG-3 cells were investigated by Northern analysis for further elucidation of the regulatory mechanisms of RAs (Fig. 6). Treatment of cells with $100 \mathrm{nM} \mathrm{Ro} 40$ for $24 \mathrm{~h}$ resulted in a stronger induction of $\mathrm{P} 450$ arom expression than treatment with $100 \mathrm{nM}$ at-RA or 9 cis-RA. This stimulation, as expected, was blocked by simultaneous administration of $1.0 \mu \mathrm{M}$ Ro41, which also decreased the effects of at-RA and 9cis-RA. Unexpectedly, in addition to being induced by at-RA (9.6-fold), 9cis-RA ( $8 \cdot 5$-fold) and Ro40 (6-8-fold), 17HSD1 expression was also increased by Ro41 (3.6-fold). Furthermore, Ro41 in combination with at-RA and 9cis-RA caused 28- and 24-fold induction respectively. On the other hand, co-treatment with Ro40 and Ro41 resulted in an additive increase in 17HSD1 expression.

Effects of Ro40 and Ro41 on reductive $17 \mathrm{HSD}$ activity in JEG-3 cells

To confirm the stimulatory influence of Ro40 and Ro41 on 17HSD 1 expression, the reductive 17HSD activity of cultured JEG-3 cells was determined after the same treatment of the cells as for mRNA analysis. Stimulation with $100 \mathrm{nM}$ at-RA, 9cis-RA and Ro40 as well as $1 \mu \mathrm{M}$
Ro41 led to 2.5-, 2.5- 2.3- and 1.7-fold increases in reductive $17 \mathrm{HSD}$ activity respectively. After the cells had been treated with $1 \mu \mathrm{M}$ Ro41 in combination with $100 \mathrm{nM}$ at-RA, 9cis-RA and Ro40, the induction was potentiated to $5 \cdot 4-, 5 \cdot 2-$ and $3 \cdot 4$-fold respectively (Fig. 7).

\section{Effect of Ro41 on HSD17B1 enhancer}

Reporter gene analysis, using the construct pBL $(-661$ / - 392)CAT2 and the control vector pBLCAT2, was conducted to further understand how Ro41 affects the transcription of the HSD17B1 gene. In the construct pBL $(-661 /-392)$ CAT2, the HSD17B1 enhancer containing an RA response element (RARE) at the position from -512 to -479 is linked to a thymidine kinase (TK) promoter, whereas pBLCAT2 merely has a TK promoter (Piao et al. 1995). Reporter gene analysis showed that the TK promoter alone has almost no activity and cannot be induced by at-RA treatment in both T47D and JEG-3 cells. When it was connected with the HSD17B1 enhancer, however, the TK promoter displayed significant transcriptional activity (Fig. 8). In T47D cells, Ro41 $(1 \mu \mathrm{M})$ did not affect $\mathrm{pBL}(-661 /-392) \mathrm{CAT}$ expression, but blocked the effect of at-RA $(100 \mathrm{nM})$ remarkably. In JEG-3 cells, treatment with $100 \mathrm{nM}$ at-RA and $1 \mu \mathrm{M}$ Ro41 enhanced $\mathrm{pBL}(-661 /-392) \mathrm{CAT}$ expression to $260 \%$ and $130 \%$ respectively. After the cells were stimulated with both at-RA and Ro41, the CAT expression was additively increased to $300 \%$ (Fig. 8). 


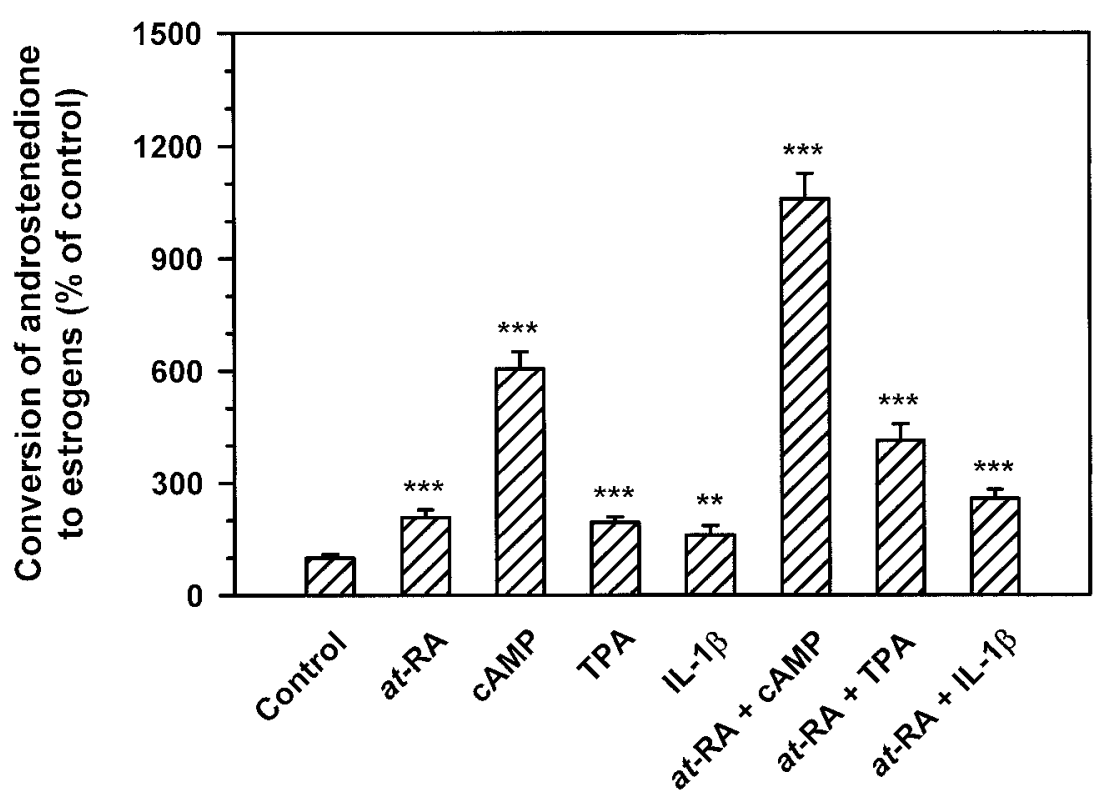

Figure 3 Interaction of at-RA with various factors on aromatase activity in JEG-3 cells. Aromatase activity was examined after the cells had been incubated for $24 \mathrm{~h}$ with (1) vehicle, (2) $100 \mathrm{nM}$ at-RA, (3) $1.5 \mathrm{mM} 8 \mathrm{Br}$-cAMP (cAMP), (4) $20 \mathrm{nM}$ TPA, (5) $25 \mathrm{pg} / \mathrm{ml}$ IL-1 $\beta$, (6) $100 \mathrm{nM}$ at-RA+1.5 mM 8Br-cAMP, (7) $100 \mathrm{nM}$ at-RA+20 nM TPA, and (8) $100 \mathrm{nM}$ at-RA $+25 \mathrm{pg} / \mathrm{ml} \mathrm{IL}-1 \beta$. The data show the means \pm range of two independent experiments with duplicate samples in each. ${ }^{* *} P<0 \cdot 01,{ }^{* * *} P<0 \cdot 001$.
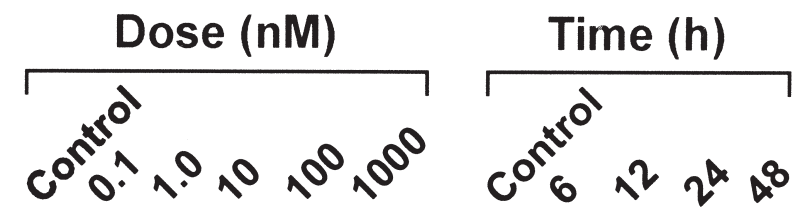

\section{P450arom}
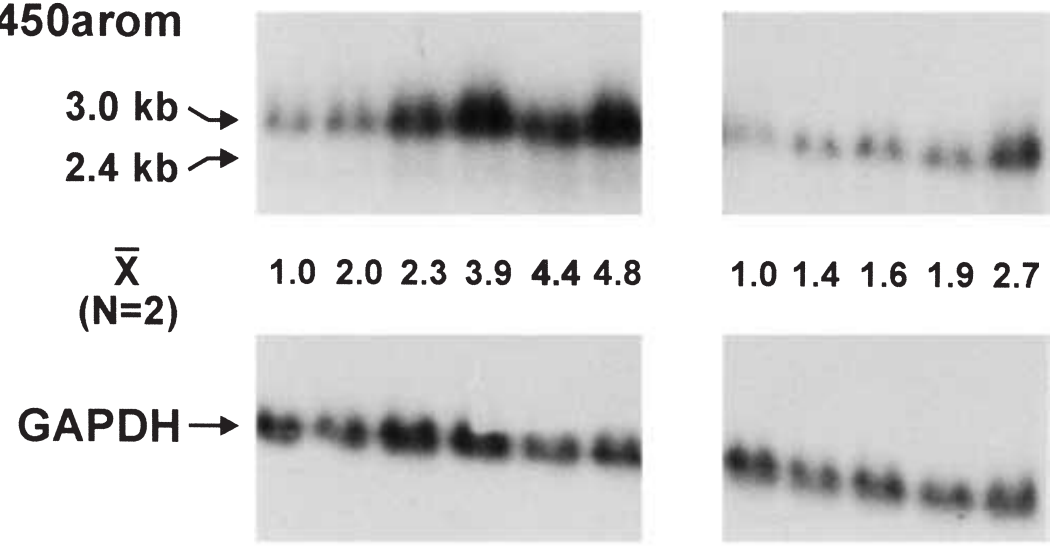

$\begin{array}{lllll}1.0 & 1.4 & 1.6 & 1.9 & 2.7\end{array}$

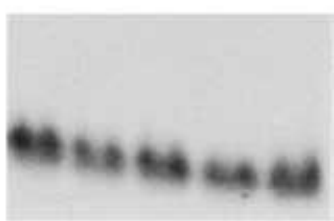

Figure 4 Dose- and time-effect of at-RA on P450arom mRNA expression in JEG-3 cells. The cells were treated with $0 \cdot 1-1000 \mathrm{nM}$ at-RA for $48 \mathrm{~h}$ (left panel), or $100 \mathrm{nM}$ at-RA for 6-48 h (right panel). Northern blot analysis was performed using total RNA isolated from the treated cells. The positions of the $3.0 \mathrm{~kb}$ and $2.4 \mathrm{~kb}$ P450arom transcripts are indicated by the arrows. The numbers below the P450arom signals represent the intensity ratio ( $3.0 \mathrm{~kb}$ P450arom/GAPDH) compared with the values (defined as 1.0) of the control samples. Two independent experiments were done with similar results and representative figures are shown. 


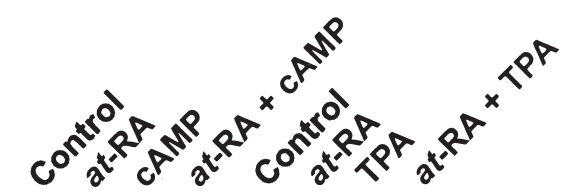

P450arom

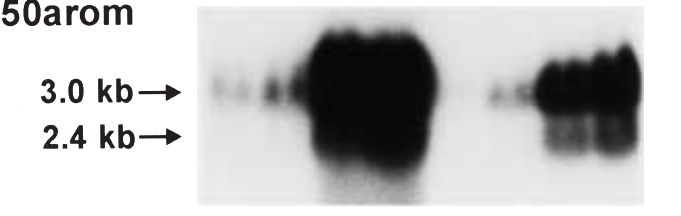

GAPDH $\rightarrow$

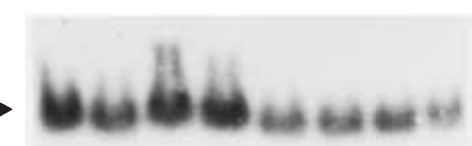

Figure 5 Effects of at-RA, 8Br-cAMP and TPA on P450arom mRNA expression in JEG-3 cells. The cells were treated for $24 \mathrm{~h}$ with vehicle, $100 \mathrm{nM}$ at-RA, $1.5 \mathrm{mM} 8 \mathrm{Br}$-cAMP (cAMP), and $100 \mathrm{nM}$ at-RA+1.5 mM 8Br-cAMP in one experiment (left panel), as well as with vehicle, $100 \mathrm{nM}$ at-RA, $20 \mathrm{nM}$ TPA and $100 \mathrm{nM}$ at-RA + $20 \mathrm{nM}$ TPA in another (right panel). Northern blot analysis was performed after treatment using total RNA isolated from the treated cells. Two independent experiments were done with similar results, and representative data are shown. Because the strong expression caused the overlap of some hybridization signals, densitometry analysis was not performed.

\section{$R A R$ and RXR transcripts in JEG-3 cells}

In order to further investigate the possible mechanisms of RAs, especially the profile of retinoid receptors, RT-PCR analysis was performed using total RNAs isolated from JEG-3 cells as the template and the primer set specific to each subtype of RXR and RAR. As shown in Fig. 9, $\operatorname{RAR} \alpha$ and $\operatorname{RXR} \alpha$ were found whereas other members of RXR and RAR could not be detected.

Effects of RAs on the expression of 17HSD1 and P450arom $m R N A$ in cultured CTB cells

Finally, the expression of 17HSD1 and P450arom in CTB cells was also examined. Upon stimulation with $100 \mathrm{nM}$ at-RA or 9 cis-RA for $24 \mathrm{~h}$, the expression of the $3.0 \mathrm{~kb}$ mRNA of P450arom in CTB cells was increased to $130 \%$ by at-RA and $170 \%$ by 9 cis-RA. $17 \mathrm{HSD} 1$ expression was also elevated by the same treatment, but to a lesser extent (Fig. 10).

\section{Discussion}

Estrogens play a crucial role during human pregnancy (Loriaux et al. 1972). Even though it is well known that the placenta is the major site of estrogen production in pregnant women, the primary factor(s) affecting estrogen biosynthesis are difficult to define because of the
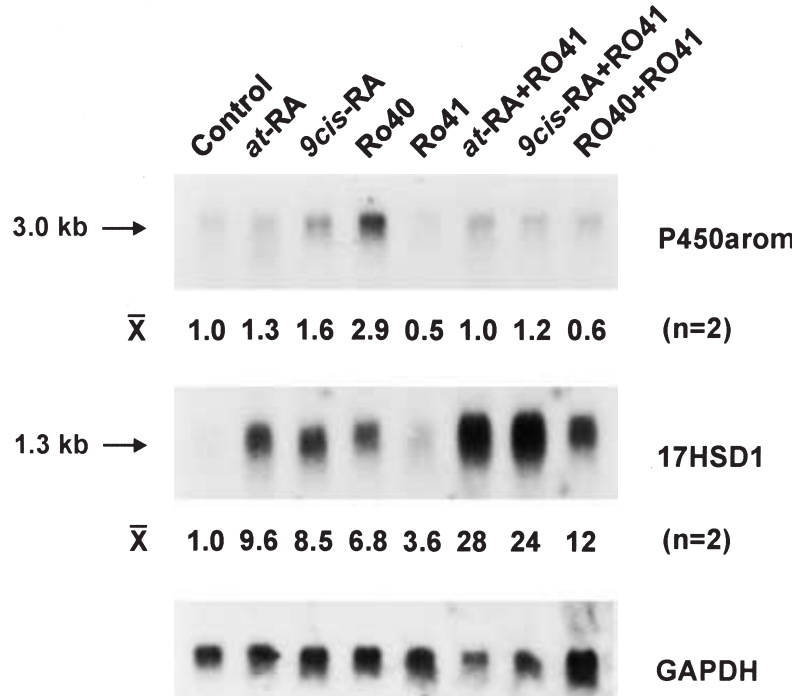

Figure 6 Influence of the selective RAR $\alpha$ antagonist (Ro41) on RA-induced P450arom and 17HSD1 mRNA expression in JEG-3 cells. The cells were treated for $24 \mathrm{~h}$ with (1) vehicle, (2) $100 \mathrm{nM}$ at-RA, (3) $100 \mathrm{nM} 9$ cis-RA, (4) $100 \mathrm{nM}$ Ro40, (5) $1.0 \mu \mathrm{M}$ Ro41, (6) $100 \mathrm{nM}$ at-RA+1.0 $\mu \mathrm{M}$ Ro41, (7) $100 \mathrm{nM} 9$ cis-RA+1.0 $\mu \mathrm{M}$ Ro41, and (8) $100 \mathrm{nM}$ Ro40+1.0 $\mu \mathrm{M}$ Ro41. Northern blot analysis was performed using total RNA isolated from the treated cells. The same membrane was probed sequentially with cDNA probes for 17HSD1, P450arom, and GAPDH. The positions of P450arom and $17 \mathrm{HSD} 1$ transcripts are indicated by the arrows. The numbers bellow the P450arom and 17HSD1 signals represent the intensity ratio $(3.0 \mathrm{~kb}$ P450arom/GAPDH and 17HSD1/GAPDH) compared with the values (defined as $1 \cdot 0$ ) of the control samples. Two independent experiments were done with similar results and representative data are shown.

complexity of the placental endocrine environment. The present study showed that $\mathrm{RAs}$ promote $\mathrm{E}_{2}$ production not only in JEG-3 cells but also in CTB cells isolated from normal placenta. These results indicate that RAs may act as regulatory factors of $E_{2}$ biosynthesis in the placenta.

P450arom and 17HSD1 play essential roles in placental $\mathrm{E}_{2}$ biosynthesis. We recently demonstrated that RAs stimulate 17HSD1 expression in JEG-3 cells, and the effect is mediated by an RARE in the enhancer region of the HSD17B1 gene, which encodes 17HSD1 (Piao et al. 1995, 1997b). In the present work, it was revealed that aromatase is also subject to regulation of RAs in JEG-3 cells at the levels of both enzyme activity and P450arom mRNA expression. The data further demonstrate that RAs play a role in regulating key steroidogenic enzymes in choriocarcinoma cells.

The expression of the CYP19 gene in the placenta and choriocarcinoma cells is controlled by a distal promoter I.1 located adjacently upstream of exon I.1 in the gene (Means et al. 1991). Recently, an imperfect palindromic sequence $5^{\prime}$-AGGTCATGCCCC-3', situated at the region from -183 to -172 within the promoter has been identified to be functional as an RARE. This sequence binds the 


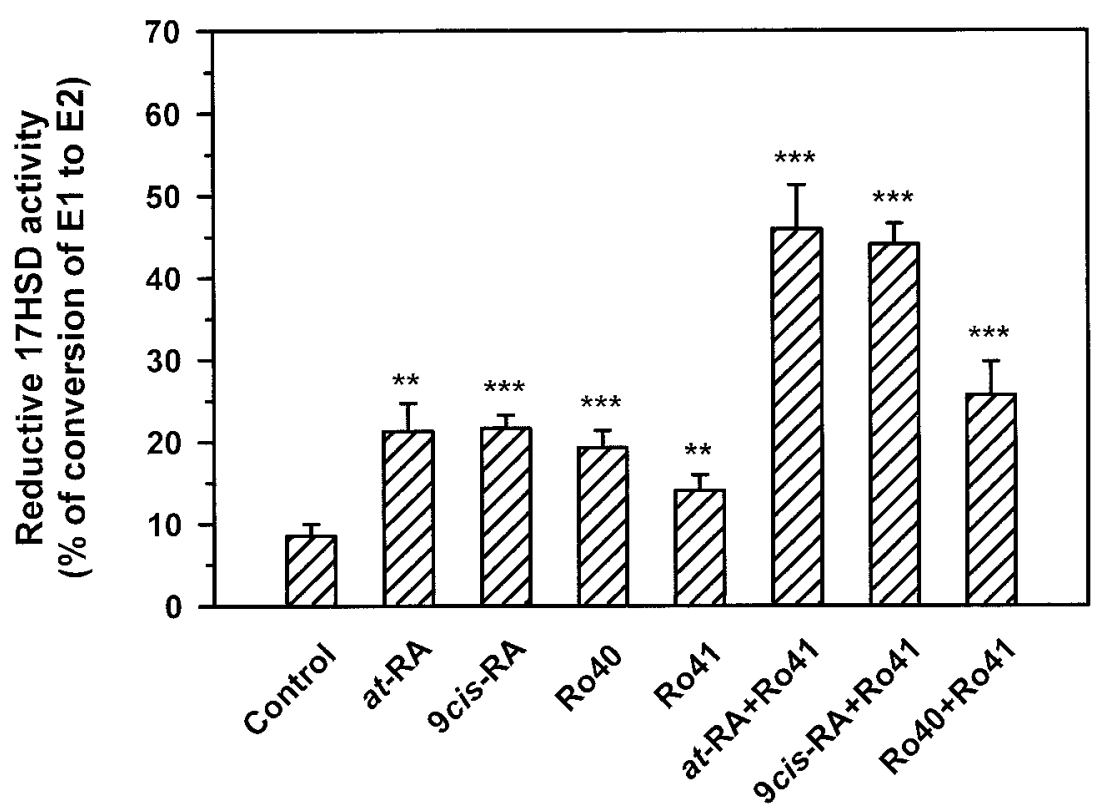

Figure 7 Effect of RAs, Ro40 and Ro41 on reductive 17HSD activity in cultured JEG-3. Reductive 17HSD activity was detected after the cells had been treated for $24 \mathrm{~h}$ with (1) vehicle, (2) $100 \mathrm{nM}$ at-RA, (3) $100 \mathrm{nM}$ 9cis-RA, (4) $100 \mathrm{nM}$ Ro40, (5) $1.0 \mu \mathrm{M}$ Ro41, (6) $100 \mathrm{nM}$ at-RA+1.0 $\mu \mathrm{M}$ Ro41, (7) $100 \mathrm{nM} 9$ cis-RA+1.0 $\mu \mathrm{M}$ Ro41, and (8) $100 \mathrm{nM}$ Ro40 $+1 \cdot 0 \mu \mathrm{M}$ Ro41. The results are presented as means \pm S.D. of three independent experiments with duplicate samples in each. ${ }^{*} P<0 \cdot 01,{ }^{* *} P<0 \cdot 001$.

$\mathrm{RXR} \alpha / \mathrm{VDR} \alpha$ (vitamen D receptor $\alpha$ ) heterodimer and mediates transactivation of promoter I.1 by RXR- and VDR-selective agonists in JEG-3 cells (Sun et al. 1998). In the bandshift experiment, the complex formed by this element and nuclear extracts isolated from JEG-3 cells was not recognized by the specific antibody against $\operatorname{RAR} \alpha$, indicating that the sequence is not bound by the RXR $\alpha$ / RAR $\alpha$ heterodimer. On the other hand, the RARselective ligand TTNBP induced the promoter activity as well as the aromatase activity, indicating that RXR/RAR heterodimer(s) are involved in regulating the expression of the CYP19 gene in JEG-3 cells (Sun et al. 1998). In the present study, RT-PCR analysis showed that JEG-3 cells express only $\operatorname{RXR} \alpha$ and $\operatorname{RAR} \alpha$. It was also found that at-RA, the ligand for RARs, as well as Ro40, a specific ligand for RAR $\alpha$, induced P450arom mRNA expression and, further, this induction was blocked by Ro41, the selective inhibitor for RAR $\alpha$. Collectively, it is indicated that another element, which can interact with $\mathrm{RXR} \alpha$ / $\operatorname{RAR} \alpha$ heterodimer, may exist in the regulatory region in the CYP19 gene.

In this study, we observed that a short-period stimu lation $(6 \mathrm{~h})$ with at-RA resulted in a maximal increase in aromatase activity in JEG-3 cells. On the other hand, the influence on the mRNA expression of P450arom appeared to be time-dependent, reaching the highest value at $48 \mathrm{~h}$ as examined. Also, the extent of induction on enzyme activity was higher than that on mRNA expression. Thus, the action of RAs on aromatase in choriocarcinoma cells may occur at translational or posttranslational levels, in addition to increasing the transcription of the CYP19 gene or stabilization of P450arom transcripts.

P450arom expression in choriocarcinoma cells is regulated by the protein kinase $\mathrm{A}$ and protein kinase $\mathrm{C}$ pathways (Ritvos \& Voutilainen 1992). Also, IL-1 $\beta$ stimulated the aromatase activity in CTB cells (Nestler 1993). The present study demonstrated that the induction of RAs on aromatase activity is enhanced by cAMP, TPA and IL-1 $\beta$ in JEG-3 cells. In addition, both cAMP and TPA elevated the RA-induced expression of P450arom mRNA. It should be noted that, compared with retinoids, cAMP and TPA appeared to be more potent inducers for P450arom expression. However, retinoids are nutritional molecules exclusively available in the placenta and therefore have the potential to play a significant role in the biosynthesis of $\mathrm{E}_{2}$. The above data, together with our recent finding that a number of factors, such as EGF, TPA, cAMP and calcium ion, interact with RAs in regulating the action of 17HSD1 in JEG-3 cells (Piao et al. 1997b), indicate that $\mathrm{E}_{2}$ biosynthesis in trophoblastic cells may be controlled by complicated mechanisms.

Apart from aromatase and 17HSD1, 3HSD1 also participates in placental $\mathrm{E}_{2}$ biosynthesis by catalyzing the conversion of DHEA to A-dione. Thus, the effect of RAs on the expression of 3HSD1, if any, may also count for 


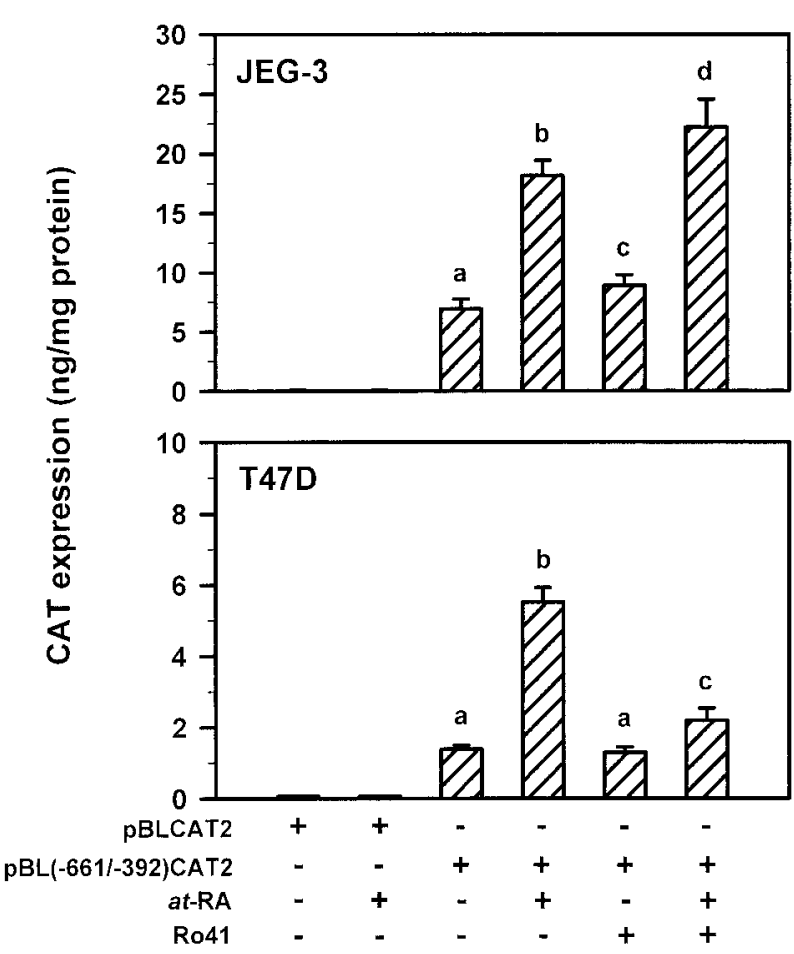

Figure 8 Effects of at-RA and Ro41 on HSD17B1 enhancer activity. The cells were transfected with the reporter gene vector pBLCAT2 or the construct $\mathrm{pBL}(-661 /-392)$ CAT2 for $18 \mathrm{~h}$. After that, the cells transfected with $\operatorname{pBL}(-661 /-392)$ CAT2 were treated with $100 \mathrm{nM}$ at-RA, $1 \mu \mathrm{M}$ Ro41 and $100 \mathrm{nM}$ at-RA+1 $\mu \mathrm{M}$ Ro41 for $48 \mathrm{~h}$. Then the cells were collected and their CAT activities were examined. The results represent the means \pm S.D. from four independent experiments, duplicate samples were analyzed in each. Bars without the same letter are significantly different from each other $(P<0 \cdot 05)$.

increased production of $\mathrm{E}_{2}$ from DHEA. However, the conversion of $\mathrm{A}$-dione to $\mathrm{E}_{2}$, which does not involve the action of 3 HSD1, was similarly induced by RAs in JEG-3 cells, implying that aromatase and 17HSD1 are the main targets for the action of RAs, at least in JEG-3 cells.

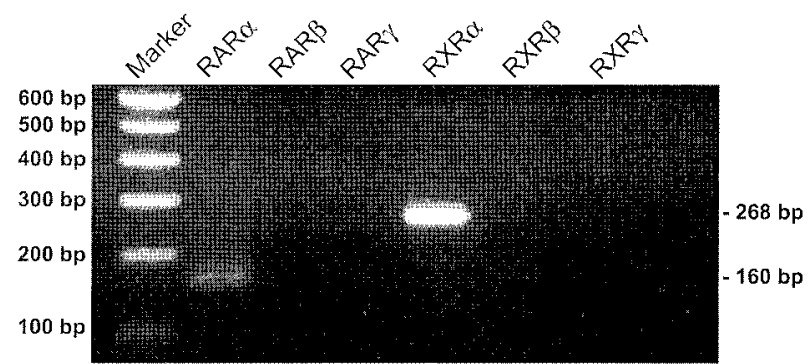

Figure 9 RT-PCR analysis of RXRs and RARs in JEG-3 cells. Gel photograph shows the result of RT-PCR amplification, which generated the cDNA fragment of RAR $\alpha(160 \mathrm{bp})$ and $R X R \alpha$ (268 bp), using total RNA isolated from JEG-3 cells as the template. Three independent experiments were done with same results and representative data are shown.
17HSD1
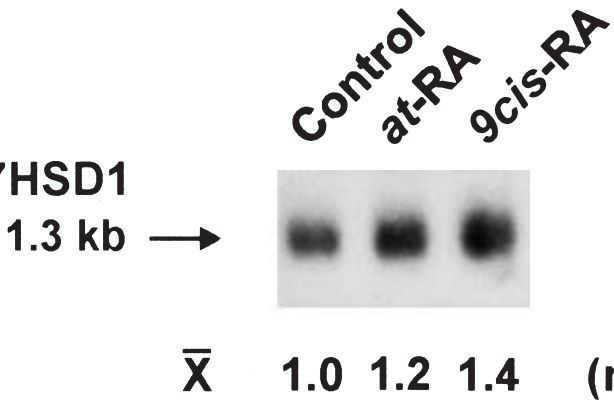

$(n=6)$

P450arom

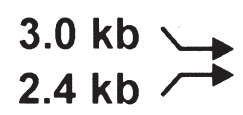

$\overline{\mathrm{X}} \quad 1.0 \quad 1.31 .7$

$(n=6)$

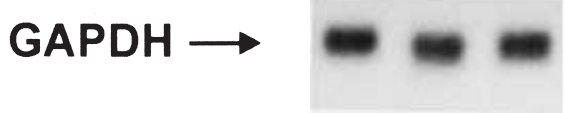

Figure 10 Effects of RAs on 17HSD1 and P450arom mRNA expression in primary cultured CTB cells. Cultured CTB cells were stimulated with $100 \mathrm{nM}$ at-RA or 9cis-RA for $24 \mathrm{~h}$. The same membrane was subjected to hybridization with CDNA probes for 17HSD1, P450arom and GAPDH. The positions of P450arom and 17 HSD 1 transcripts are indicated by the arrows. The numbers below the P450arom and 17HSD1 signals represent the average intensity ratio $(3.0 \mathrm{~kb}$ P450arom/GAPDH and 17HSD1/GAPDH) compared with the values (defined as 1.0) of the control samples. Six independent experiments were done with similar results and representative data are shown.

Ro41 has been identified to act as a selective antagonist for RAR a (Apfel et al. 1992), but this does not readily explain the effect of Ro41 on 17HSD1 expression in JEG-3 cells. In a previous report, Ro41 was demonstrated to inhibit the stimulation of at-RA on 17HSD1 expression in breast cancer T47D cells (Reed et al. 1994). Correspondingly, this study also showed that Ro41 blocks the activation of at-RA on the transcription of the HSD17B1 gene in the same cells. In contrast, Ro41 induced the expression and activity of 17HSD1 in JEG-3 cells and, moreover, potentiated the effects of RAs. However, the same phenomenon was not identically observed in reporter gene analysis showing that, although Ro41 was able to increase the enhancer activity in JEG-3 cells, the extent was noticeably less than its influence on the abundance of 17HSD1 mRNA. Moreover, the combined effect of Ro41 and at-RA on HSD17B1 enhancer in JEG-3 cells was only additive, not as synergistic as was found in mRNA analysis of 17HSD1. Therefore, the effect of Ro41 on the expression of 17HSD1 in JEG-3 cells seems 
to occur at both transcriptional and post-transcriptional levels, especially the mRNA stabilization. Alternatively, Ro41 may activate a subtype of retinoid receptors, which is targeted to an unknown regulatory area in the HSD17B1 gene rather than the RARE located at the region from -512 to -479 . Nevertheless, this phenomenon is probably specific to JEG-3 cells, because Ro41 did block the stimulatory effect of at-RA on 17HSD1 expression in breast cancer cells (Reed et al. 1994).

Accumulating evidence suggests that retinoids regulate the production of key placental hormones and steroidogenic enzymes in JEG-3 cells (Kato \& Braunstein 1991, Matsuo \& Strauss 1994, Stephanou \& Handwerger 1995, Piao et al. 1997b, Guibourdenche et al. 1998a, Tremblay et al. 1999). It was recently reported that $\operatorname{RXR} \alpha$ and RAR $\alpha$ are expressed in JEG- 3 cells, and RXR $\alpha$ mediates the biological effects of retinoids on cell function, i.e. hCG secretion. On the other hand, neither Western blot nor Northern blot analyses could detect the presence of $\operatorname{RXR} \beta, \operatorname{RXR} \gamma, \operatorname{RAR} \beta$ and RAR $\gamma$ in the JEG-3 cells (Guibourdenche et al. 1998a). In agreement with these data, our RT-PCR analysis revealed that only RAR $\alpha$ and RXR $\alpha$ are present in JEG-3 cells. Meanwhile, we found that $\operatorname{RAR} \alpha$ is also a mediator of the action of retinoids on JEG-3 cells, since Ro40, the selective ligand for RAR $\alpha$ and at-RA, the ligand for RARs, stimulated the expression of P450arom and 17HSD1 mRNA. It can also be speculated that the effects are mediated by RXR $\alpha$ / $\operatorname{RAR} \alpha$, which is the only form of heterodimer available in JEG-3 cells.

It is agreed that STB cells, which are differentiated from $\mathrm{CTB}$ cells, are mainly responsible for hormone production in the placenta. Correspondingly, P450arom and 17HSD1 are exclusively expressed in STB cells in vivo (FournetDulguerov et al. 1987). However, cultured STB cells isolated directly from the placenta cannot be used as a model for in vitro studies because of their lack of viability under cell culture conditions. On the other hand, in vitro cultured CTB cells possess some features of STB cells, such as the ability to produce hCG, $\mathrm{E}_{2}$ and progesterone (Kliman et al. 1991, Zhuang \& Li 1991). They could therefore be employed as a cell model to investigate the mechanisms of steroidogenesis in the placenta. In this study, it was clearly shown that CTB cells cultured in vitro express both P450arom and 17HSD1, and are capable of producing $\mathrm{E}_{2}$ from DHEA. In situ hybridization and immunohistochemical staining also confirmed 17HSD1 expression in $\mathrm{CTB}$ cells during the first trimester (our unpublished data).

In the human placenta, $\operatorname{RAR} \alpha$ and $\operatorname{RXR} \alpha$ are the major forms of retinoid receptors expressed in trophoblastic cells, and RXR $\alpha$ has been proved to be involved in regulating the production of hCG and leptin (Roulier et al. 1994, Guibourdenche et al. 1998b,c). In line with these observations, the present study demonstrated that at-RA, the ligand for RARs and especially 9cis-RA, the ligand for
RXRs, can promote $\mathrm{E}_{2}$ production as well as the expression of P450arom and 17HSD1 mRNA in cultured CTB cells. On the other hand, the extent of the induction of RAs on P450arom and 17HSD1 expression is less than that on the conversion of DHEA to $\mathrm{E}_{2}$ in CTB cells, suggesting that RAs may also act on the translational or post-translational levels of these two enzymes.

In brief, the results of the present study demonstrate that RAs promote the biosynthesis of $E_{2}$ in placental cells by increasing the expression of aromatase and 17HSD1 gene, but the mechanisms of the divergent effects of Ro41 on gene expression in JEG-3 cells remain to be elucidated.

\section{Acknowledgements}

The authors wish to thank Ms Helmi Konola for her skillful technical assistance in this work, and Professor Lin-zhi Zhuang for her helpful comment on this study. This work was supported by the Chinese Academy of Sciences (Project STZ-2-14 and Knowledge Innovation Program), the National Natural Science Foundation of China (Project 39700052), the Academy of Finland, the Research Fund for Returned Overseas Chinese Scholars from the Ministry of Human Resource, the Chinese Academy of Sciences, and the Ministry of Education, China.

\section{References}

Albrecht ED \& Pepe GJ 1990 Placental steroid hormone biosynthesis in primate pregnancy. Endocrine Reviews 11 124-150.

Apfel C, Bauer F, Creitaz M, Forni L, Kamber M, Kaufmann F, LeMotte P, Pirson W \& Klaus M 1992 A retinoic acid receptor- $\alpha$ antagonist selective counteracts retinoic acid effects. PNAS $\mathbf{8 9}$ 7129-7133.

Bahn RS, Worsham A, Speeg KV Jr, Ascoli M \& Rabin D 1981 Characterization of steroid production in cultured human choriocarcinoma cells. Journal of Clinical Endocrinology and Metabolism 52 447-450.

Conley AJ \& Mason JI 1990 Placental steroid hormones. Clinical Endocrinology and Metabolism 4 249-272.

Corbin CJ, Graham-Lorence S, McPhaul M, Maxon JI, Mendelson CR \& Simpson ER 1988 Isolation of a full length cDNA insert encoding human aromatase system cytochrome P-450 and its expression in nonsteroidogenic cells. PNAS 85 8948-8952.

Evans CT, Corbin CJ, Saunders CT, Merril JC, Simpson ER \& Mendelson CR 1987 Regulation of estrogen biosynthesis by human adipose stromal cells: effects of dibutyl cyclic AMP, epidermal growth factor, and phorbol ester on the synthesis of aromatase cytochrome P-450. Journal of Biological Chemistry 262 6914-6920.

Fournet-Dulguerov N, MacLusky NJ, Leranth CZ, Mendelson CR, Simpson ER \& Maftolin F 1987 Immunohistochemical localization of aromatase cytochrome P-450 and oestradiol dehydrogenase in the syncytiotrophoblast of human placenta. Journal of Clinical Endocrinology and Metabolism 65 757-764.

Ghersevich SA, Poutanen MH, Martikainen HK \& Vihko R 1994 Expression of $17 \beta$-hydroxysteroid dehydrogenase in human granulosa cells: correlation with follicular size, cytochrome P450 aromatase activity and oestradiol production. Journal of Endocrinology 143 139-150. 
Guibourdenche J, Roulier S, Rochette-Egly C \& Evain-Brion D 1998a High retinoid X receptor expression in JEG-3 choriocarcinoma cells: involvement in cell function modulation by retinoids. Journal of Cell Physiology 176 595-601.

Guibourdenche J, Alsat E, Soncin F, Rochette-Egly C \& Evain-Brion D $1998 b$ Retinoid receptor expression in human term placenta: involvement of $\mathrm{RXR} \alpha$ in retinoid induced-hCG secretion. Journal of Clinical Endocrinology and Metabolism 83 1384-1387.

Guibourdenche J, Tarrade A, Laurendeau I, Rochette-Egly C, Chambon P, Vidaud M \& Evain-Brion D 1998c Retinoids stimulate leptin synthesis and secretion in human syncytiotrophoblast. Journal of Clinical Endocrinology and Metabolism $\mathbf{8 5}$ 2550-2555.

Jenkins C, Michael D, Mahendron M \& Simpson E 1993 Exon-specific northern analysis and rapid amplification of cDNA ends (RACE) reveal that the proximal promoter II (PII) is responsible for aromatase cytochrome P450 (CYP19) expression in human ovary. Molecular and Cellular Endocrinology 97 R1-R6.

Kato Y \& Braunstein GD 1991 Retinoic acid stimulates placental hormone secretion by choriocarcinoma cell lines in vitro. Endocrinology 128 401-407.

Kilgore MW, Means GD, Mendelson CR Simpson ER 1993 Alternative promotion of aromatase cytochrome P450 in human fetal tissues. Molecular and Cellular Endocrinology 83 R9-R16.

Kliman J, Strauss JF III, Kao L-C, Caltabiano S \& Wu S 1991 Cytoplasmic and biochemical differentiaton of the human villous cytotrophoblast in the absence of syncytium formation. Trophoblast Research 5 297-309.

Leivonen S, Piao YS, Peltoketo H, Nunchaisrika P, Vihko R \& Vihko P 1999 Identification of essential subelements in the hHSD17B1 enhancer: difference in function of the enhancer and the hHSD17 BP1 analogue is due to $-480 \mathrm{C}$ and $-486 \mathrm{G}$. Endocrinology 140 3478-3487.

Loriaux DL, Ruder HJ, Knab DR \& Lipsett MB 1972 Estrone sulfate, estrone, estradiol and estriol plasma levels in human pregnancy. Journal of Clinical Endocrinology and Metabolism 35 887-891.

LuuThe V, Labrie C, Simard J, Lachance Y, Zhao H-F, Couet J, Leblanc G \& Labrie F 1990 Structure of two in tandem human $17 \beta$-hydroxysteroid dehydrogenase genes. Molecular Endocrinology 4 268-275.

Mahendroo MS, Mendelson CR \& Simpson ER 1993 Tissue-specific and hormonally-controlled alternative promoters regulate aromatase cytochrome P450 in human adipose tissue. Journal of Biological Chemistry 268 19463-19470.

Matsuo H \& Strauss JF III 1994 Peroxisome proliferators and retinoids affect JEG-3 choriocarcinoma cell function. Endocrinology 135 $1135-1145$.

Means GD, Mahendroo MS, Corbin CJ, Mathis JM, Powell FE, Mendelson CR \& Simpson ER 1989 Structural analysis of the gene encoding human aromatase cytochrome P-450, the enzyme responsible for estrogen biosynthesis. Journal of Biological Chemistry 264 19385-19391.

Means GD, Kilgore MW, Mahendroo MS, Mendelson CR \& Simpson ER 1991 Tissue-specific promoters regulate aromatase cytochrome P450 gene expression in human ovary and fetal tissues. Molecular Endocrinology 5 2005-2013.

Miettinen M, Mustonen M, Poutanen M, Isomaa V \& Vihko R 1996 Human 17 $\beta$-hydroxysteroid dehydrogenase type 1 and type 2 isoenzymes have opposite activities in cultured cells and characteristic cell- and tissue-specific expression. Biochemical Journal 314 839-845.

Mu YM, Yanase T, Nishi Y, Hirase N, Goto K, Takayanagi R \& Nawata H 2000 A nuclear receptor system consisted by RAR and RXR induces aromatase activity in MCF-7 human breast cancer cells. Molecular and Cellular Endocrinology 166 137-145.

Nestler JE 1993 Interleukin-1 $\beta$ stimulates the aromatase activity of human placental cytotrophoblasts. Endocrinology 132 566-570.
Neumann JR, Morency CA \& Russian KO 1987 A novel rapid assay for chloramphenicol acetyltransferase gene expression. Biotechniques 5 444-447.

Peltoketo H, Isomaa V \& Vihko R 1992 Genomic organization and DNA sequence of human $17 \beta$-hydroxysteroid dehydrogenase genes and flanking regions. Localization of multiple Alu sequences and putative cis-acting elements. European Journal of Biochemistry 209 459-466.

Piao YS, Peltoketo H, Oikarinen J \& Vihko R 1995 Coordination of transcription of the human $17 \beta$-hydroxysteroid dehydrogenase type 1 gene (EDH17B2) by a cell-specific enhancer and a silencer: identification of a retinoid acid response element. Molecular Endocrinology 9 1633-1644.

Piao YS, Peltoketo H, Vihko P \& Vihko R 1997a The proximal promoter region of the gene encoding human $17 \beta$-hydroxysteroid dehydrogenase type 1 contains GATA, AP-2 and Sp1 response elements: analysis of promoter function in choriocarcinoma cells. Endocrinology 138 3417-3425.

Piao YS, Peltoketo H, Jouppila A \& Vihko 19976 Retinoic acids increase $17 \beta$-hydroxysteroid dehydrogenase type 1 expression in JEG-3 and T47D cells, but the stimulation is potentiated by epidermal growth factor, 12-O-tetratradecanoylphorbol-13-acetate and cyclic adenosine $3^{\prime}, 5^{\prime}$-monophosphate only in JEG-3 cells. Endocrinology 138 898-904.

Pompon D, Liu RYK, Besman MJ, Wang PL, Shively JE \& Chen S 1989 cDNA cloning and expression of human placental aromatase in Saccharomyces cerevisiae. Molecular Endocrinology 3 1477-1487.

Reed MJ, Rea D, Duncan LJ \& Parker MG 1994 Regulation of estradiol $17 \beta$-hydroxysteroid dehydrogenase expression and activity by retinoic acid in T47D breast cancer cells. Endocrinology 135 4-9.

Ritvos O \& Voutilainen R 1992 Regulation of aromatase cytochrome P-450 and 17 $\beta$-hydroxysteroid dehydrogenase messenger ribonucleic acid levels in choriocarcinoma cells. Endocrinology 130 61-67.

Rong-Hao L, Luo S \& Zhuang LZ 1996 Establishment and characterization of a cytotrophoblast cell line from normal placenta of human origin. Human Reproduction 11 1328-1333.

Roulier S, Rochette-Egly C, Rebut-Bonneton C, Porquet D \& Evain-Brion D 1994 Nuclear retinoic acid receptor characterization in cultured human trophoblast cells: effect of retinoic acid on epidermal growth factor receptor expression. Molecular and Cellular Endocrinology 105 165-173.

Simpson ER \& MacDonald PC 1981 Endocrine physiology of the placenta. Annual Review of Physiology 43 163-188.

Simpson ER, Mahendroo MS, Means GD, Kilgore MW, Hinshelwood MM, Graham-Lorence S, Amarnen B, Ito Y, Fisher CR, Michael MD, Mendelson CR \& Bulun SE 1994 Aromatase cytochrome P450, the enzyme responsible for estrogen biosynthesis. Endocrine Reviews 15 342-355.

Steinkampf MP, Mendelson CR \& Simpson ER 1987 Regulation by follicle-stimulating hormone of the synthesis of aromatase cytochrome P-450 in human granulosa cells. Molecular Endocrinology $1465-471$.

Stephanou A \& Handwerger S 1995 Retinoic acid and thyroid hormone regulate placental lactogen expression in human trophoblast cells. Endocrinology 136 933-938.

Sun T, Zhao Y, Mangelsdorf DJ \& Simpson ER 1998 Characterization of a region upstream of exon I.1 of the human CYP19 (aromatase) gene that mediates regulation by retinoids in human choriocarcinoma cells. Endocrinology 139 1684-1691.

Thompson EA \& Siiteri PK 1974 The involvement of human placental microsomal P450 in aromatization. Journal of Biological Chemistry 249 5373-5378.

Toda K \& Shizuta Y 1993 Molecular cloning of a cDNA showing alternative splicing of the $5^{\prime}$ untranslated sequence of mRNA for human aromatase P450. European Journal of Biochemistry 13 383-389. 
Tremblay J, Hardy DB, Pereira LE \& Yang K 1999 Retinoic acid stimulates the expression of $11 \beta$-hydroxysteroid dehydrogenase type 2 in human choriocarcinoma JEG-3 cells. Biology of Reproduction $\mathbf{6 0}$ 541-545.

Xu P, Wang YL, Zhu SJ, Luo SY, Piao YS \& Zhuang LZ 2000 Expression of matrix metalloproteinase-2, -9 , and -14 , tissue inhibitors of metalloproteinase-1, and matrix proteins in human placenta during the first trimester. Biology of Reproduction 62 988-994.

Xu P, Wang YL, Piao YS, Bai SX, Xiao ZJ, Jia YL, Luo SY \& Zhuang LZ 2001 Effects of matrix proteins on the expression of metalloproteinase-2, -9 and -14 , and tissue inhibitors of metalloproteinases in human cytotrophoblast cells during first trimester. Biology of Reproduction 65 240-246.

Zhuang LZ \& Li RH 1991 Study on reproductive endocrinology of human placenta (II): hormone secreting activity of cytotrophoblast cells. Science in China B 34 1092-1097.

Received 16 September 2001

Accepted 28 September 2001 